Rok XV (2020) | 2 (30)|S. 221-244

https://doi.org/10.12797/LV.15.2020.30.17

Maciej Rak (๑)

Uniwersytet Jagielloński, Kraków

maciej.rak@uj.edu.pl

\title{
KRAKOWSKIE LISTY JANA BAUDOUINA DE COURTENAY DO JANA KARŁOWICZA Z 1894 R.
}

Słowa klucze: Jan Baudouin de Courtenay, Jan Karłowicz, historia polskiego językoznawstwa Keywords: Jan Baudouin de Courtenay, Jan Karłowicz, history of Polish linguistics

Korespondencja Jana Baudouina de Courtenay do Jana Karłowicza, pochodząca z lat 1875-1879 i przechowywana we Lwowskiej Narodowej Naukowej Bibliotece Ukrainy im. Wasyla Stefanyka, została opracowana przez Josipa O. Dzendzelivs'kiego (2003). Inna cześć tej korespondencji znajduje się w Litewskim Państwowym Archiwum Historycznym (lit. Lietuvos valstybès istorijos archyvas) w Wilnie, gdzie jest skatalogowana pod sygnaturą 1135, dział 10, nr 98 (Письма к Яну Карловичу и др. од лиц на букву А и В (1840-1903)). Jest to zasób dość obszerny, obejmuje jednostki archiwalne o numerach od 479 do 673 , co daje razem 194 listy i karty pocztowe. Fotokopię tej korespondencji przygotowałem podczas pobytu w Wilnie w dniach 11-16 II $2019 \mathrm{r}$. Zgodnie z planem pozyskane $\mathrm{w}$ ten sposób materiały mieliśmy opracować wspólnie z Profesorem Mirosławem Skarżyńskim, świetnym znawcą twórczości, życiorysu i epistolografii J. Baudouina de Courtenay. Profesor przeprowadził wstępne rozeznanie, wymieniliśmy kilkadziesiąt maili na ten temat, niestety postępująca ciężka choroba, w wyniku której zmarł 23 VIII 2019 r., na zawsze przerwała naszą współpracę.

Postanowiłem wydać część listów w numerze „LingVariów”, który jest dedykowany Mirosławowi Skarżyńskiemu. Z konieczności dokonuję tu wyboru i prezentuję korespondencję z 1894 r., którą J. Baudouin de Courtenay wysyłał z Krakowa, gdy był profesorem w Katedrze Językoznawstwa Porównawczego i Sanskrytu na 
Uniwersytecie Jagiellońskim. Dziewięć listów i dziewięć kart pocztowych pokazuje m.in. stosunki naukowe i pozanaukowe panujące w Krakowie w ostatniej dekadzie XIX w., przy czym - ze względu na adresata - ich treść dotyczy też Warszawy. Przewija się tu kilka nazwisk, poza Lucjanem Malinowskim, z którym J. Baudouin de Courtenay nie utrzymywał bliższych kontaktów, pojawiają się odniesienia do Jana Rozwadowskiego i Kazimierza Nitscha. Brakuje tu tylko Jana Łosia (przybył do Krakowa z Petersburga w 1902 r. już po wyjeździe Baudouina), by mówić o krakowskiej szkole językoznawczej.

Głównymi tematami naukowymi publikowanej korespondencji są: 1) komentowanie etymologii leksemów opracowywanych przez J. Karłowicza do Słownika wyrazów obcego a mniej jasnego pochodzenia używanych w języku polskim (SWOKarł), 2) sprawy dotyczące zmian w polskiej pisowni oraz 3) uwagi związane z redagowaniem Słownika warszawskiego (SW). Jak wiadomo (por. Boryś 1989: 486; Majdak 2008: 202), Baudouin przez jakiś czas (trudno tu o precyzję, gdyż nie ma ten temat właściwie żadnych dokładnych informacji) prowadził dział etymologiczny w SW. Z opublikowanych tu listów wynika, że komentował i poprawiał, a być może także ustalał etymologię wyrazów rodzimych uwzględnionych w SWOKarł. Czy przy tej okazji myślał o opracowaniu własnego słownika etymologicznego? Trudno o jednoznaczną odpowiedź.

Przygotowując edycję, ujednoliciłem i uwspółcześniłem interpunkcję i ortografię (m.in. wprowadziłem zapis $d w o ́ c h$, w oryginale było $d w u c h$ ). Zachowałem autorskie przekreślenia i dawniejsze formy wyrazów, np. rękopism i przyszle, w nawiasach kwadratowych rozwiązałem skróty i dodałem przypisy objaśniające.

\section{Literatura (wybór)}

Boryś W., 1989, Jan Baudouin de Courtenay jako etymolog, [w:] J. Rieger, M. Szymczak, S. Urbańczyk (red.), Jan Niecisław Baudouin de Courtenay a lingwistyka światowa. Materiały z konferencji międzynarodowej. Warszawa 4-7 IX 1979, Wrocław - Warszawa Kraków - Gdańsk - Łódź, s. 483-486.

Czelakowska A., Skarżyński M., 2011, Materiały do dziejów polskiego językoznawstwa. Listy Jana Niecisława Baudouina de Courtenay, Jana Łosia, Kazimierza Nitscha, Jana Michała Rozwadowskiego, Henryka Ułaszyna, „Biblioteka LingVariów”, t. 8, Kraków.

Dzendzelìvs'KIJ J.O., 2003, Materiali do istoriï pol's'koï ta slov'ânskoï filologì. XI (č. 1). Vibrane listuvannâ Â. Boduena de Kurtene $z \hat{A}$. Karlovičem, „Prace Filologiczne” XLVIII, S. $143-222$.

MAJDAK M., 2008, Słownik warszawski. Koncepcja - realizacja - recepcja, Warszawa.

Nitsch K., 1960, Ze wspomnień językoznawcy, Kraków.

PSB: W. Konopczyński i in. (red.), Polski słownik biograficzny, t. I-LI, Warszawa - Kraków 1935-.

RAK M., 2018, Materiały do dziejów polskiej dialektologii i etnologii. Listy Cezarii Baudouin de Courtenay-Ehrenkreutz-Jędrzejewiczowej, Adama Fischera, Antoniego Kaliny, Izydora 
Kopernickiego, Kazimierza Nitscha, Seweryna Udzieli, Juliusza Zborowskiego, „Biblioteka LingVariów”, t. 25, Kraków.

Rieger J., Szymczak M., Urbańczy K S. (red.), Jan Niecisław Baudouin de Courtenay a lingwistyka światowa. Materiały z konferencji międzynarodowej. Warszawa 4-7 IX 1979, Wrocław - Warszawa - Kraków - Gdańsk - Łódź.

SKARŻYŃski M. (oprac.), 2016, Materiały do dziejów polskiego językoznawstwa. II: Jan Baudouin de Courtenay. Teksty mniej znane, „Biblioteka LingVariów”, t. 21, Kraków.

SKArŻyński M., Smoczyńska M. (oprac.), 2007, Listy Jana Baudouina de Courtenay do Henryka Ułaszyna z lat 1898-1929, „Biblioteka LingVariów”, t. 1, Kraków.

SW: J. Karłowicz, A.A. Kryński, W. Niedźwiedzki (red.), Słownik języka polskiego, t. I-VIII, Warszawa 1900-1927.

SWOKarŁ: J. KarŁoWICZ, Słownik wyrazów obcego a mniej jasnego pochodzenia używanych w języku polskim, Kraków 1894-1905.

Życie i prace Jana Karłowicza (1836-1903). Książka zbiorowa wydana staraniem i nakładem redakcji „Wisły”, Warszawa 1904.

\section{L}

Kraków, 8 I [18]94

Ul. Radziwiłłowska 13

Kochany Kolego!

Od siostry mojej żony ${ }^{1}$ dostaliśmy tu lis kartkę pani Kirkorowej², która donosi, że gotowi jesteście starać się o umieszczenie powieści siostry w jednym z czasopism warszawskich i że prosicie tak o przysłanie tego rękopismu, jako też listu o nim Chmielowskiego ${ }^{3}$. Otóż tedy ten rękopism jest u mnie, ale z wysłaniem go powstrzymam się do otrzymania od Was samych potwierdzenia wiadomości, zakomunikowanej przez panią K[irkoro]wą. Co zaś do listu Chmielowskiego, to podczas przenosin zapodział mi się gdzieś i dotychczas nie mogę go znaleźć. Pamiętam jednak mniej więcej jego treść. Pisał on mniej więcej, że temat główny jest bardzo dobrze dobrany i widocznie ze znajomością rzeczy obrobiony, ale że miłość traktowana jest niezbyt udatnie, a ogól pracy opowiadanie trochę za rozwlekłe. Zdaje mi się, że raziła Chmiel[owskie]go zbytnia może idealność miłości, co się zapewne tym objaśnia, iż dzisiaj przyzwyczailiśmy się do abyk arcyrealnego traktowania tego uczucia, do traktowania przypominającego:

Kaśka za piec, Maciek za niq

1 Janina Baudouin de Courtenay (1862-1942), bratowa Jana i siostra jego żony, pisarka.

2 Maria Celestyna Kirkorowa (1840-1931), druga żona Adama Honorego Kirkora (1819-1886), działaczka społeczna.

3 Prawdopodobnie mowa o Piotrze Chmielowskim (1848-1904), historyku literatury, encyklopedyście, profesorze Uniwersytetu we Lwowie, który w latach 1882-1897 był redaktorem „Ateneum”. 
z dodaniem wykończenia, odpowiadającego wyższemu stopniu cywilizacji. Co do rozwlekłości, to może Chmielowski miał rację, chociaż znowu powieść mojej bratowej (i siostry mojej żony) jest nierównie mniej rozwlekła aniżeli wiele innych powieści drukowanych w Warszawie w ostatnich czasach. Zresztą autorka chętnie by skróciła, ale to wymagałoby gruntownych przeróbek, połączonych ze znaczną stratą czasu, którego jej absolutnie brak, wobec konieczności zaj doglądania i obszywania trojga małoletnich dzieci, z których najmłodsza panna kończy teraz właśnie pierwszy rok swojego życia. Wytknięte przez Chmielowskiego rusycyzmy żona moja starannie poprawiła.

Dodam tylko, że na wydrukowaniu tej powieści nadzwyczaj wiele zależy autorce ze względu na smutne ich położenie materialne. Hydrukowanie Honorarium byłoby niepoślednią zapomogą.

Czekam tedy waszej prędkiej odpowiedzi, a jeżeli będzie potwierdzająca, rękopism natychmiast wyszlę.

Po Dla lepszej rekomendacji pani Janiny dodam, iż drukowała ona już dwie op powiastki, które się dosyć podobają, a mianowicie Żydziątko w „Prawdzie” 1889, $\mathrm{N} 16^{4}$ i O jedno spojrzenie w „Tygodniku Ilustrowanym” 1890, NN 15-18

Kryński ${ }^{6}$ zwrócił Wam już mój dług $\mathrm{N} 2$ (o zwróceniu nru 1 także myślę). Upraszam Was bardzo o zniszczenie odpowiedniego rewersu, który wysłałem ongi na ręce Kryńskiego. Niepotrzebnie tylko potrąciliście 11 r[ubli] 42 k[opiejki], które posłałem przecież na rachunek po należnych Wam procentów. Obecnie natomiast posyłam 6 kuponów wartości nominalnej 15 rub[li]. Dostaniecie tedy za nie 14 rub[li] 25 kop[iejek], które proszę zapisać na rachunek procentu.

W nowym roku serdeczne życzenia wszystkiego najlepszego dla obojga Państwa od nas obojga.

Pani rączki całuję, a Was, kochany Kolego, ściskam serdecznie.

Wiernie oddany J. Baudouin de Courtenay

4 J. Baudouin de Courtenay, Żydziątko. Opowiadanie, „Prawda” IX, 1889, nr 16, s. 182-185.

5 J. Baudouin de Courtenay, O jedno spojrzenie. Z odczytanego notatnika ładnej panny, „Tygodnik Ilustrowany" 1890 , $\mathrm{nr}$ 15, s. 234-235, nr 16, s. 250-251, nr 17, s. 266-267, nr 18, s. 282-283.

6 Adam Antoni Kryński (1844-1932), filolog, językoznawca, współautor Słownika warszawskiego, założyciel (w 1884 r.) i redaktor „Prac Filologicznych”, redaktor „Wisły”, profesor Uniwersytetu we Lwowie (1908-1914) i Uniwersytetu Warszawskiego (1915-1919). 


\section{K}

Wielmożny

Dr Jan Karłowicz (И.А. Карловичу)

Warszawa

Ul. Jasna (Ясная) 10

Kraków, 14 I [18]94

[Ul.] Radziwiłłowska 13

Kochany Kolego!

Dziękuję za list z 11 bm. Rękopism p[ani] Janiny załączam. Był on dotychczas jedynie u Chmielowskiego, tak że inne redakcje nic o nim jeszcze nie wiedzą. Gdyby się udało umieścić go, byłoby to prawdziwym dobrodziejstwem dla autorki. O działalności uniwersyteckiej w „syreniem grodzie” myśleć nie mogę, choćby ze względu na "grzech pierworodny". A zresztą zresztą stosunki są tam tak miłe, że trudno byłoby tam wytrzymać z moim usposobieniem. Ważną też jest sprawa wychowania dzieci, a wyglądająca tam potwornie. Być może, że się tu jakoś oswoję, chociaż niezaradność i niedołęstwo polskie dają się we znaki na każdym kro kroku. Ale są też też pewne dobre strony. Czy mię tu kiedy zutylizują, nie wiem. Zabawny jest ów strach przed ezei ez czcigodnym panem L[ucjanem] M[alinowskim] ${ }^{7}$ (współredaktorem „Prac Filol[ogicznych]”). Teraz dopiero zabio mogę się zabrać do pracy systematycznej, a więc także do słownika etymol[ogicznego] (dalszy ciąg). Odsyłacze do pni

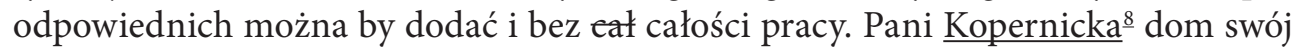
sprzedała i wyniosła się z Krakowa do swojej córki Orlikowskiej9

\section{Zawsze wierny J. Baudouin de Courtenay}

7 Lucjan Malinowski (1839- 898), absolwent (podobnie jak Jan Baudouin de Courtenay) Szkoły Głównej Warszawskiej, dialektolog, historyk języka, profesor filologii słowiańskiej na Uniwersytecie Jagiellońskim, członek PAU.

8 Maria Kopernicka (1830-?) z Berezowskich, wdowa po Izydorze Kopernickim (1825-1891).

9 Magdalena Orlikowska. 


\section{K}

Wielmożny

Dr Jan Karłowicz

Ul. Jasna 10

Warszawa

Kochany Kolego!

Kraków, 6 II [18]94

W cej- (ceć-) formą pierwotną zdaje się być ceć, a cej powstało tak samo jak ojca, wiejski, rajca... Z tego względu nie można myśleć o zestawianiu wprost $\mathrm{z}$ csłow. ${ }^{10} u$ u bu, chociaż ce, rzecz oczywista, mogłoby odpowiadać fonetycznie csłowu u̧b. Prócz tego związek znaczeniowy nie jest dla mnie całkiem jasny. Czy nie można by rozkładać tak:

$$
\text { ce }-\dot{c}
$$

i widzieć w ć zwykłe polskie $c(\leftarrow c ́ i \leftarrow t i)$ [w co-ć, b bo-ć, a to ci smyrga...], w ce zaś for modyfikację če, co?

Byłoby wtedy $\check{c} \breve{l}$ (quid) $\rightarrow \check{c} e(\wedge \rightarrow c o) \rightarrow c e$ (chociaż owo upodobnienie do co jest trochę naciągane). Zresztą zdaje się to być wyraz pochodzenia mazurskiego, a więc wtedy eo ipso

$\check{c} \rightarrow c$

$\check{c} e \rightarrow c e$.

W każdym razie etymologia to bardzo wątpliwa.

Serdecznie pozdrowienia od nas obojga do obojga Państwa

Wiernie oddany

J. Baudouin de Courtenay

4. L

Kochany Kolego!

Kraków, 27 II [18]94

Ul. Radziwiłłowska 13 II

Jelínek ${ }^{11}$ przysłał mi kilka egzemplarzy swego dziełka Zapomenutý kout slovanský12, z których jeden dla Was. Oddałem ten egzemplarz księgarni Gebethnera z poleceniem przesłania go do Warszawy. Może więc zechcecie upomnieć się o tę książkę u warszawskiego Gebethnera.

10 Język starocerkiewnosłowiański.

11 Edvard Jelínek (1855-1897), czeski publicysta, zwolennik współpracy polsko-czeskiej, publikował artykuły m.in. w „Tygodniku Ilustrowanym” i „Kłosach”.

12 E. Jelínek, Zapomenutý kout slovanský: několik prvních pohledů do kašubského pomoři, Praha 1894. 
Dano mi tu do przeczytania list Floriana Czepielińskiego ${ }^{13}$ (do jednego z moich kolegów ze Szkoły Głównej ${ }^{14}$ ), w którym narzeka na redakcję Słownika [warszawskiego], że doznał zawodu. Słyszał podobno najprzód od jednego ze współpracowników, że za zbierane wyrazy płacą po gr[oszy] 5 od kartki; kiedy jednak przyniósł pierwszy tysiąc, oświadczono mu, że nie dostanie więcej jak po 1 kopiejce od sztuki. Zgodził się na to Próez tego i przysyłał co kilka tygodni opracowane i uzbierane wyrazy. Prócz tego zakomunikowano mu, że rezerwują dla niego $S$ i $Z$ z pochodny$\mathrm{mi}^{15}$. W kwietniu jednak oświadezono mut „odmówiono mu dalszej pracy głównej” i proszono go jedynie o zbieranie wyrazów brakujących w słownikach. Takich wyrazów wysłał on z Kamieńca 70oo. Zbierał je w dalszym ciągu, posiłkując się głównie biblioteką śp. doktora Rolle ${ }^{16}$. W przeciągu roku uzbierał znowu przeszło 20000 wyrazów i przesłał je do Warszawy w nadziei, że dostanie za nie przynajmniej po kopiejce. Tymczasem po 9 miesiącach oświadczono mu, że nie dostanie więcej jak po pół kopiejki. Wobec tego odebrał swoje kartki, a po sprawdzeniu przekonał się, że zginęło ich półtora tysiąca. Oprócz tego zebrał od wiesny wiosny znowu kilkanaście tysięcy. Tak więc, nie tieząe licząc owych zużytkowanych 10 ooo, posiada jeszcze 32 ooo kartek z wyrazami, których albo zupełnie nie ma w słownikach, albo definicja tam niedokładna, albo z rzędem odmiennym, albo w przenośnym znaczeniem [sic!] lub z odmienną formą. Gorąco on pragnie, aby jego praca zasiliła nowy słownik, ale niepodobna mu zgodzić się na wynagrodzenie 150 rubli za 22-miesięczną ciągłą pracę źródłową. „Toż drwal więcej zarabia”. Zwraca się więc Czepieliński do owego mojego kolegi z prośbą: „czy nie zechciałby kto z bogatych panów galicyjskich czy podolskich zrobić ofiary i nabyć ode mnie kartki dla wcielenie ich do nowego słownika, przynajmniej po 2 kopiejki od sztuki, albo może Akademia Krakowska ma na to fundusz?".

Przytaczam Wam treść owego listu, bo zwrócono się do mnie o radę, a zanim będę mógł dać, pragnąłbym usłyszeć Wasze zdanie w tej sprawie jako osoby najkompetentniejszej. Jak by należało postąpić, aby dopomóc Czepielińskiemu bez uszczerbku dla samej sprawy? O ile jego zażalenia są słuszne? Czy kartki jego posiadają wartość? Czy istotnie mogło zaginąć półtora tysiąca? Może były źle zapakowane i wypadły zapodzialy się gdzieś podczas transportu, czy to z Kamieńca do Warszawy, czy też z Warszawy do Kamieńca.

13 Florian Czepieliński (1822-1900), pedagog, gramatyk i leksykograf, jeden z współautorów Słownika wileńskiego. Opracował także Gramatykę języka polskiego praktyczno-teoretyczna, ułożona według programatu obowiązującego dla szkół Królestwa Polskiego. Kurs I-II (Warszawa 1871-1872) oraz Stownik polsko-rosyjski, administracyjno-sadowo-techniczny z tabela synoptyczna rang i stopni rosyjskich (Warszawa 1867).

14 J. Baudouin de Courtenay studiował w Szkole Głównej Warszawskiej w latach 1862-1866.

15 Hasła na litery $S$ i $Z$ Czepieliński opracował wcześniej do Słownika wileńskiego.

16 Józef Apolinary Rolle (1830-1894), lekarz psychiatra, historyk amator Kresów, przez całe niemal życie związany z Kamieńcem Podolskim. 
Zabrałem się do porządkowania swych materiałów do słownika etymologicznego, ale po kilku dniach musiałem dać pokój. Zwaliły się bowiem na mnie liczne korekty, a mam prawdziwe szczęście do korekt jeżących się błędami wymagających t ogromnej straty czasu. Były to i są jeszcze korekty z Krakowa (dwie), z Petersburga, $z$ Udine, z Bonn ( $z$ „Indogerm[anische] Forschungen” ${ }^{17}$ ). W Udine niejaki Loschi ${ }^{18}$ wydaje Katechizm rezjański ${ }^{19}$ w mojej transkrypcji regionalnej wraz z obszernym wstępem; i oto przysyła mi także korektę, która pochłonie chyba z tydzień czasu. Wobec tego prędka praca nad słownikiem etymologicznym jest niemożliwa. Niech mię zresztą usprawiedliwi to, że Polonus sum et nihil polonii (a więc także marudztwo, niezaradność i niedołęstwo) a me alienum esse putto. Odsyłacze jednak do słownika etymologicznego można wnosić do tekstu słownika. Mogę więc nadesłać odpowiednie odsyłacze do liter $a A$ i $b B$. Jeżeli zaś będzie brakowało do jakiego wyrazu, proszę mię zawiadomić, a dopełnię. Myślę, że za jakie 2-3 tygodnie będę mógł wysłać ów spis wyrazów z $A$ i $B$ z odsyłaczami do słownika etymologicznego.

Serdeczne pozdrowienia i uściski od zawsze wiernego J. Baudouina de Courtenay

\section{K}

Wielmożny

Dr Jan Karłowicz

Warszawa

Ul. Jasna 10

Kochany Kolego!

Kraków, 16 III [18]94

Tymczasem te słów kilka, później więcej. Dzięki w imieniu pani Janiny za za starania o umieszczenie jej powieści oraz oświadczenie w jej imieniu, że zgadza się zupełnie na sposób drukowania i warunki zaproponowane przez Skiwskiego ${ }^{20}$. Adres jej:

Янина Ромуальдовна Бодуэн де Куртенэ

Петербург, Петербургская сторона, Грезной [?] пер. N 3, кв. 8.

Ale już została o wszystkim zawiadomioną, więc nie potrzebujecie jej pisać. 5 rubli za arkusz to niewiele, ale zawsze lepiej jak nic (+ butwienie rękopismu). Zdaje się, że Gebethner przesłał Wam Zapomenutý kout [slovanský], przecież to chyba

17 „Indogermanische Forschungen” - czasopismo językoznawcze (rocznik) założone w 1892 r. przez Friedricha Karla Brugmanna i Wilhelma Streitberga, wychodzi do dziś.

18 Giuseppe Loschi (1858-1937), włoski nauczyciel, publicysta, tłumacz z języka rosyjskiego.

19 J. Baudouin de Courtenay, Il catechismo resiano, con una prefazione del dott. Giuseppe Loschi, Udine 1894.

20 Jan Kazimierz Skiwski (1867-1925), warszawski drukarz, redaktor i wydawca tygodników „Przyjaciel Dzieci” i „Tygodnik Mód i Powieści”. 
cenzuralne. Zgłoście się więc do warszawskiego Gebethnera. Oddałem dziś także Gebethnerowi 5 egz. swojej Próby teorii alternacji fonetycznych ${ }^{21}$ : dla Was, dla Kryńskiego, Appela ${ }^{22}$, Taczanowskiego ${ }^{23}$ i Smirnowa ${ }^{24}$. Ma to wysłać do Warszawy około 1 kwietnia.

Cześć i pozdrowienia J. Baudouin de Courtenay

\section{K}

Wielmożny

Dr Jan Karłowicz

Warszawa

Ul. Jasna 10

Kochany Kolego!

Kraków, 23 III [18]94

Znów tylko tymczasowa odpowiedź. Dzięki: za starania w sprawie pani Janiny, jak również za przyczynek do kolae kolekcji Naturschreiberów ${ }^{25}$. Zapomenutý kout [slovanský] powinien już być w Warszawie. Próba alternacji fon [etycznych] ma być wyprawiona po 1 kwietnia. Wczoraj dopiero przysłał mi Gebethner zesz[yt] I Waszego Słownika wyrazów obcych ${ }^{26}$.

Czy czasem guldynka nie jest w związku z miastem Goldingen jako ojczyzną takich strzelb? (cf. berlinka, najtyczanka, manczester, damaszek, nankin...). Na gruszt nie mam idealnych cytat, oprócz Lindego. Ale z Lindego wnoszę, że to jest mniej więcej rusztowanie, fundament, podstawa...

Od nas obojga obojgu Państwu serdeczne pozdrowienia

Wiernie oddany

J. Baudouin de Courtenay

21 J. Baudouin de Courtenay, Próba teorii alternacji fonetycznych. Cz. I ogólna, „Rozprawy Wydziału Filologicznego Akademii Umiejętności w Krakowie" XX, 1894, s. 219-364; też odb. Kraków 1893; też po niemiecku: Versuch einer Theorie phonetischer Alternationen. Ein Kapitel aus der Psychophonetik, Strasburg - Kraków 1895.

22 Karol Appel (1857-1930), językoznawca, zaczynał jako nauczyciel języka francuskiego w V Gimnazjum w Warszawie, po 1918 r. związany z Uniwersytetem Warszawskim (był profesorem językoznawstwa ogólnego), zainteresował się językoznawstwem pod wpływem prac A.A. Kryńskiego i J. Baudouina de Courtenay.

23 Wacław Taczanowski (1868-1904), językoznawca, pedagog, tuż przed śmiercią (na wojnie japońskiej) rozpoczął pracę nad wydaniem 4 tomu Słownika gwar polskich J. Karłowicza; wspólnie z Hieronimem Łopacińskim zdążył zredagować jedynie trzy pierwsze arkusze tego tomu.

24 Николай А. Смирнов - autor pracy Западное влияние на русский язык в Петровскую эпоху, Санкт-Петербург 1910.

25 Niem. dosł. „pisarz przyrody”.

26 Mowa o Karłowicza Słowniku wyrazów obcego a mniej jasnego pochodzenia, którego zeszyt pierwszy obejmujący hasła na litery A-E wyszedł w Krakowie w 1894 r. 


\section{K}

Wielmożny

Dr Jan Karłowicz

(И.А. Карловичу)

(Król[estwo] Polskie)

Nałęczów pod Lublinem

Налэнчовь (Любл. г.)

Kraków, 12 IV [18]94

Ul. Radziwiłłowska 13

Kochany Kolego!

Dziś dopiero odsyłam do Lwowa referat w sprawie pisowni... ${ }^{27}$ Prawie nic w nim nie zmieniłem. Zdaniem moim ustępować nie należy. Jeżeli nie wydrukują, to można wydrukować gdzie indziej. Że tutejsi boją się podpisywać, to nic dziwnego. Panuje tu bowiem azjatycki despotyzm i nietolerancja. Przekonałem się, że „Akademia Umiejętności” jest właściwie „hrabstwem” Um[iejętności] („hrabstwo” jak własność p[ana] hrabiego $\left.{ }^{28}\right)$; przekonałem się zaś przy sposobności przedstawienia nowych członków Kom[isji] Antrop[ologicznej] ${ }^{29}$, w tej liczbie dwóch pań (horrendum!). Opowiem Wam to za widzeniem się.

A kto podpisuje nasz referat? Ja wiem tylko o czterech: Brückner ${ }^{30}$, Kryński, Wy i ja. Panna Schultz ${ }^{31}$ z Wenecji zapytuje, czy otrzymaliście: 1) jej list, 2) zesz. odbitkę z „Rivista Musicale [Italiana]” z jej [La] berceuse populaire $\left.{ }^{32}, 3\right)$ programy koncertów. Byłem w Wiedniu i rozmawiałem o swej sprawie z Rittnerem ${ }^{33}$; przestawiłem się także ministrowi.

Życzenie wszystkiego dobrego i serdeczne pozdrowienia

Szczerze oddany

J. Baudouin de C.

27 J. Baudouin de Courtenay, Aleksander Brückner, Antoni Kalina, J. Karłowicz, A.A. Kryński, Sprawa przyjęcia jednolitej pisowni, proponowanej przez Akademię Umiejętności w Krakowie, „Pamiętnik Zjazdu Literatów i Dziennikarzy Polskich”, t. I, 1894, s. 1-27.

28 Mowa o hrabim Stanisławie Tarnowskim (1837-1917), historyku literatury, profesorze i dwukrotnym rektorze Uniwersytetu Jagiellońskiego, prezesie AU w latach 1890-1917.

29 Od lutego do października 1894 r. J. Baudouin de Courtenay był przewodniczącym Komisji Antropologicznej AU.

30 A. Brückner (1856-1939), slawista, historyk literatury i kultury polskiej, profesor Uniwersytetu Berlińskiego.

31 Ella von Schultz-Adajewsky [w literaturze też: Scholutz-Adajewska] (1846-1926), pochodząca z Petersburga pianistka i kompozytorka, członkini Komisji Antropologicznej AU.

32 E. von Schultz-Adjewsky, La Berceuse Populaire, „Rivista Musicale Italiana” 1894, s. 240-256.

33 Edward Rittner (1845-1899), prawnik, profesor i rektor Uniwersytetu we Lwowie, poseł do Sejmu Krajowego Galicji w latach 1882-1899. 


\section{L}

Kraków, 10 V [18]94

Ul. Radziwiłłowska 13 II

Kochany Kolego!

Wczoraj otrzymałem Wasz list z 8 bm., a dziś wysłałem żądany wykaz pni. Chciałem posłać od razu więcej i dlatego się ociągnąłem, a robić w ostatnich czasach mogłem bardzo mało, skutkiem silnej apatii i zniechęcenia. Posyłam nie tylko część żądaną (od a $B$ do bankietować), ale także trochę więcej (od samego początku do barłóg). Pnie podaję w formie dostępnej poczuciu każdego Polaka, bo to uważam za najwłaściwsze i najbardziej zgodne z wymaganiami nauki obiektywnej. Na podstawie dopiero takich pni można robić zestawienia $z$ innymi językami oraz wykazywać przekształcenia składu pni (zrastanie się ich, rozszczepianie itp.; wszystko to będzie uwzględnione w moim słowniku etymologicznym ${ }^{34}$ ).

Pisownię pni przyjmuję cokolwiek inną, ażeby uwydatnić od razu ich skład fonetyczny. Gdyby się Wam $x(c h)$ nie podobało, można zamienić je inną jaką literą, np. $h$, ale koniecznie pojedynczą. Zresztą wszelkie uwagi i poprawki przyjmę z wdzięcznością.

Przy sposobności załączam także trochę wyrazów, zebranych przeze mnie dorywczo, a przeznaczonych na wcielenie do Waszego sł słownika. Prawdopodobnie są one one Wam znane; ale może ten lub ów będzie nowością. Przy niektórych podaję mog tylko trochę odmienne znaczenie, przy innych znowu dodatek do objaśnienia. Następnie będę przesyłał dalszy ciąg.

Odsyłam też wyrazy Czepielińskiego, a w tym liście kwit pani Czepielińskiej ${ }^{35}$.

Był tu u mnie Kubala ${ }^{36}$ i proponował mi, ażebym ja wniósł na zjeździe lwowskim $^{37}$ referat o pisowni. Motywuje on tę propozycję względem na Wasz i Kryńskiego udział w Komisji, stanowiącej owe Uchwały Akademii, i jesteście więc niby poniekąd stroną zagłosowaną. Ja tymczasem nie byłem wcale wówczas wzywany do narad i dlatego wyglądam niby bezstronniej. Odpowiedziałem Kubali warunkowo, robiąc moje od wystąpienie zależnym: 1) od zgody Waszej, 2) od mojej możności pojechania do Lwowa (a brak mi na to tak czasu, jako też pieniędzy).

Kubala był także u mnie i obiecał nadesłać Wam swoją zgodę. Co zrobi Malinowski, nie wiem, gdyż się bardzo rzadko widujemy, a widując się, rozmawiamy o pogodzie i in[nych] t[ym] p[odobnych] rzeczach, nie dotykając kwestii ważniejszych i naukowych.

34 Zdanie to można interpretować na dwa sposoby: 1) Baudouin nosił się z zamiarem opracowania własnego słownika etymologicznego albo 2) opracowywał (komentował) etymologię rodzimego słownictwa do SWOKarł i ten właśnie zasób nazywał „swoim słownikiem etymologicznym”. Katarzyna Czepielińska z Jacewiczów. Ludwik Kubala (1838-1918), historyk, członek PAU, badacz dziejów XVII w. Chodzi o II Zjazd Literatów i Dziennikarzy Polskich we Lwowie w dn. 18-23 VII 1894 r. Jego organizatorem było Koło Literacko-Artystyczne we Lwowie. 
Bystroniowi ${ }^{38}$ rękopism Wasz dziś jeszcze zaniosę.

Moja żona i dzieci wyjadą na lato do Skawy w okolicach Rabki, ale ja cały czas tu pozostanę, tak że z prawdziwą przyjemnością powitam Was tu w lipcu.

W Nałęczowie będzie także Taczanowski, jak mi o tym pisze w liście, również wczoraj otrzymanym.

Wracając do Słownika, pozwolę sobie jeszcze zauważyć, że - zdaniem moim pni nie należy umieszczać osobno w ogólnym słowniku, ale tylko odsyłać do nich przy pojedynczych wyrazach. Pnie jako Stichwörter jako wyrazy naczelne będą na miejscu dopiero w samym słowniku etymologicznym.

Czy otrzymaliście już Zapomenutý kout slovanský Jelínka? Bardzo proszę o prędką odpowiedź na to pytanie.

Wszakże Damian Rolicz Lieder ${ }^{39}$ jest to ten sam Lieder, który kilka lat temu wydał w Krakowie 2 tomy swoich Poezji? Niedawno znowu przysłał mi swój Elementarz arabski ${ }^{40}$.

Obojgu Państwu przesyłamy oboje najserdeczniejsze pozdrowienia i wyrazy głębokiej czci.

Wiernie oddany

J. Baudouin

\section{K}

Wielmożny

Dr Jan Karłowicz

Warszawa

Ul. Jasna 10

Kochany Kolego!

Kraków, 16 V [18]94

Gebethner tutejszy nie wysłał Wam jeszcze Zapomenutého kouta [slovanského] Jelínka, of obawiając się szponów sławetnej cenzury. Za Zachowuje go tu wraz z innymi książkami do Waszego przyjazdu.

Słyszałem dziś, że Malinowski jest niezdrów. Miał uderzenie krwi do głowy podczas wykładu. Bystroń będzie się zapewne obawiał występować przeciw Akademii. Odnosząc mu Wasz rękopism, nie zastałem go w domu i w ogóle nie widziałem go od tego czasu.

Nad słownikiem etymologicznym będę odpowiednio pracował. Jeżeli nie da się go zużytkować do Waszego słownika, postaram się wydać go całkiem osobno. Ale to dziś odległa przyszłość.

38 Jan Bystroń (1860-1902), językoznawca, uczeń L. Malinowskiego, zajmował się dialektologią, historią języka, etnografią i lituanistyką, członek PAU.

39 Wacław Damian Lieder (Rolicz-Lieder) (1866-1912), poeta, prekursor Młodej Polski.

40 D. Rolicz-Lieder, Elementarz języka arabskiego, cz. 1: Abecadlnik, Kirchhain 1893. 
Pisałem do Petersburga w sprawie bezczelnej gospodarki cenzury warszawskiej, prześladującej zawzięcie, a bez bezcelowo wydawnictwa tutejszej Akademii. Ciekawym, czy wskóram choć cokolwiek.

Wiernie oddany

J. Baudouin de Courtenay

\section{K}

Hern Dr. Jan Karłowicz

Beim Hern Zygmunt Wasilewski

Wörishofen ${ }^{41}$ (Bayern)

Villa Obrecht

Kraków, 26 VII [18]94

[Ul.] Radziwił[lowska] 13

Kochany Kolego!

W sprawie Ramułta ${ }^{42}$ „N[owa] Reforma” ${ }^{43}$ ciągle się na Was powołuje. Dziś rozmawiałem z tymi panami ( $w$ tej liczbie także z zacietrzewionym trochę Asnykiem ${ }^{44}$ ); powiadają oni: a dlaczegóż pan Karłowicz milczy? Przecież te twierdzenia oparte sa na jego zdaniu. Sądziłbym więc, że bardzo byłoby dobrze, gdybyście zechcieli zabrać głos w tej sprawie, oświadczając np. żeście nigdy nie posądzali R[amułt]a o agitację panslawistyczną lub t[ym] p[odobną]. Może przyszlecie podobny artykulik na moje ręce, a ja go doręczę redakcji „N[owej] Reformy”?

„Rivista Musicale [Italiana]” wysłałem dziś do Wörishofen, dokąd wyprawiam też do Lwowa zaś wyprawiam drugą kartkę, jednobrzmiącą z tą.

Ucałowanie rączek Pani, pani Wasilewskiej ${ }^{45}$ ukłon i pozdrowienia, a Wam uścisk serdeczny od szczerze oddanego

J. Baudouina

41 Dziś: Bad Wörishofen - uzdrowisko w Bawarii.

42 Stefan Ramułt (1859-1913), językoznawca, badacz kaszubszczyzny, etnograf, autor Słownika języka pomorskiego, czyli kaszubskiego (Kraków 1893). Słownik ten wywołał poważną dyskusję językoznawczą. Wzięli w niej udział m.in. J. Karłowicz, który był przeciwny uznaniu kaszubszczyzny za oddzielny język (por.: Raz jeszcze o kaszubszczyźnie, „Wisła” X, 1896, s. 691-692 i Gwara kaszubska, „Wisła” XII, 1898, s. 74-94) i J. Baudouin de Courtenay, który w obrębie gwar polskich wyróżnił gwary kaszubskie i gwary niekaszubskie (czysto polskie) (Иван А. Бодуэн-де-Куртенэ, Кашубский „язык”, кашубский народ и, кашубский вопрос”, odbitka z: „Журнал Министерства Народного Просвещения" СССХ, 1897 (http://books.e-heritage.ru/book/10094469, dostęp 29 II 2020)).

43 Dziennik krakowski wychodzący w latach 1882-1928.

44 Adam Asnyk (1838-1897), poeta i dramaturg.

45 Wanda Wasilewska (1868-1903), córka J. Karłowicza, żona Zygmunta Wasilewskiego, polityka Narodowej Demokracji. 


\section{L}

Kraków, 29 VII [18]94

[Ul.] Radziwiłłowska 13

Kochany Kolego!

Na rachunek należnego Wam do 1/13 listopada r[oku] b[ieżącego] procentu rocznego w ilości rub[li] 36 posyłam Wam znowu 7 kuponów wartości nominalnej $17 \mathrm{r}$ [ubli] $50 \mathrm{k}$ [opiejek], czyli po odtrąceniu 5\% podatku $16 \mathrm{rub}[\mathrm{li}] 62 \mathrm{kop[iejki],} \mathrm{a} \mathrm{że} \mathrm{w} \mathrm{stycz-}$ niu posłałem 6 podobnych kuponów (nominalnie $15 \mathrm{r}$ [ubli]) = 14,25, a więc razem opłaciłem już 30 rub[li], 87 kop[iejek], pozostaję zaś dłużnym 5,13, co razem stanowi $36 \mathrm{rub}[\mathrm{li}]$.

Czy otrzymaliście „Rivista Musicale [Italiana]”?

Najpiękniejsze poz ukłony i serdeczne pozdrowienia wszystkim Państwu

J. Baudouin de Courtenay PS Czy otrzymaliście moją kartkę, w której prosiłem, ażebyście paru słowy wystąpili także w obronie Ramułta? Boć na Was się ciągle powołują.

\section{K}

Wielmożny

Dr Jan Karłowicz

Warszawa

Ul. Jasna 10

Kochany Kolego!

Kraków, 12 IX [18]94

Korzystam z łaskawego pozwolenia Waszego i skierowuję do Państwa Józefę Borowską (niańkę naszych dzieci, powracającą do siebie). Była ona u nas lat przeszło osiem. Obszerniejszy list doręczy sama Borowska. Wyjedzie ona pojutrze w piątek o $5^{1 / 2} \mathrm{z}$ rana i stanie w Warszawie wieczorem o 8. Zajdzie wprost na ulicę Jasną.

Wiernie oddany J. Baudouin de Courtenay

13. L

Kraków, 13 IX 1894 Ul. Radziwiłłowska 13

Kochany Kolego!

List ten wręczy nasza b[yła] niańka, Józefa Borowska (osoba, zdaniem „Свота”, bardzo niebezpieczna dla nietykalności Białorusi). Będzie ona Was prosić o łaska- 
wą pomoc w nabyciu dwóch listów zastawnych albo Banku Ziemskiego Wileńskiego (Виленского Земельного Банка) ${ }^{46}$, albo też może podobnego banku ogólniepaństwowego (Крестьянский поземельный банк ${ }^{47}$ czy coś w tym rodzaju). Nie wiem, co pewniej i korzystniej, i pozostawiam to oczywiście Waszemu uznaniu*.

Prócz tego jeszcze dwie prośby:

1. Dałem tu Józefie Borowskiej od siebie rubla, ażeby kupiła jaką dobrą książkę z obrazkami dla swoich siostrzeńców. Nie chciałem nabywać tego w Krakowie, bo wydania warszawskie lepiej kupować na miejscu, a wydania tutejsze niebezpiecznie jest przewozić przez granicę. Może więc zechcecie poradzić jej, co będzie najodpowiedniejsze.

2. Dla swoich dzieci chciałbym sprowadzić egzemplarz Elementarza Promyka (dawniej kupiony egzempłarz już się dawno podarł). Może więc nie nadużyję Waszej dobroci, ażebyście polecili przy spes ności któremu z księgarzów wysłanie mi tej książeczki pod opaską, a koszt wnieśli na mój rachunek (Jeśli się nie mylę, Elementarz Promyka kosztuje 10 groszy).

[dopisek z boku:] Elementarz ten dostałem tutaj u Gebethnera.

Nareszcie ośmielam sobie przypomnieć o obietnicy dokompletowania defektowego egzemplarza „Pieśni ludu polskiego Oskara Kolberga ${ }^{48}$, oddział pierwszy poświęcony W. Zaleskiemu ${ }^{49}$... W Poznaniu, u Żupańskiego ${ }^{50}$ (1842)", stanowiącego własność Komisji Antropologicznej. Jakiś wariat wyrwał z tego egzemplarza kartkę ze str. 19-20 (zawierającą nr 23 i początek 24) (na str. 18 pieśń nr 22: Idzie żołnierz borem lasem, a na str. 21 koniec nru 24: wybijemy gwoździkami doku do kolusineczka). Otóż tedy chodzi mi o zdobycie tej kartki str. 19-20. Będąc u mnie w Krakowie po raz pierwszy, obiecaliście kazać przepisać tę kartkę. Jeżeli spełnicie to i przyszlecie mi rękopism pod opaską, zyskacie sobie wdzięczność naszej Komisji. Ów egzemplarz okaleczony stanowił niegdyś własność osobistą samego Kolberga. W tej chwili spostrzegam, że brak też karty str. 27-28 (z nrami 31, 32 i 33). O przepisanie tej karty również upraszam, oraz karty str. 41-42 (z nrami 45 i 46) i karty str. 90-91 (z N dokończeniem nru 99 i z nrem 100). O przepisanie tych wszystkich (trzech, razem czterech) kart również upraszam.

46 Bank działający w latach 1872-1939, założony przez ziemian z Wileńszczyzny pod przewodnictwem Adama Broel-Platera (1836-1909) oraz grupę finansistów warszawskich na czele z Janem Blochem (1836-1902).

47 Rosyjski bank działający w latach 1882-1917.

48 Oskar Kolberg (1814-189o), etnograf, folklorysta, autor Ludu. Jego zwyczajów, sposobu życia, mowy, podań, przysłów, obrzędów, guset, zabaw, pieśni, muzyki i tańców.

49 Wacław Zaleski (1799-1849), folklorysta, poeta, pisarz, działacz społeczny, autor Pieśni polskich i ruskich ludu galicyjskiego, Lwów 1833.

50 Jan Konstanty Żupański (1804?-1883), poznański księgarz i wydawca. 
Pani rączki całuję, a Was, kochany Kolego, ściskam serdecznie, przepraszając za sprawianie Wam bezsensownych kłopotów.

Wiernie oddany

J. Baudouin de Courtenay

* Borowska będzie mieszkać w mniejszych miastach rosyjskich, zwłaszcza nadbałtyckich, więc chodzi (czyli „rozchodzi się") o takie papiery, ażeby kupony mogła tam bez trudności zmienić.

\section{4. $K$}

Wielmożny

Dr Jan Karłowicz

Warszawa

Ul. Jasna 10

Kochany Kolego!

Kraków, 14 IX [18]94

Proszę Was bardzo, powiedzcie Józefie Borowskiej, ażeby mi jeszcze z Warszawy doniosła, jak jej poszło na granicy i czy sobie dała radę z paszportem i z biletami (tak z biletem osobowym, jako też z bagażem). Jest to osoba dosyć niepraktyczna i dlatego obawiam się, że jej się mogło przytrafić coś nieprzyjemnego. Szkoda, że nie kupiłem jej biletów wprost do Warszawy, ale po części chciałem, ażeby się w ten sposób przyzwyczajała do większej zaradności i pamiętania o sobie.

Jakże teraz z Waszym zdrowiem? Czy owa niedyspozycja już przeszła? Dzięki Wam za opiekę nad Józefą.

Pani ucałowanie rączek, a Was ściskam serdecznie

Wiernie oddany

J. Baudouin

[Ul.] Radziwiłłowska 13

15. L

Kochany Kolego!

Kraków, 28 X [18]94

[Ul.] Radziwiłłowska 13

Raczcie wybaczyć moją wrodzoną mi oraz nabytą opieszałość i nie gniewajcie się za spóźnioną odpowiedź na list Wasz z 16 września. Serdeczne dzięki składamy obojgu Państwu za zaopiekowanie się Józefą Borowską. Być bardzo może, że niedługo powróci ona do Krakowa, gdyż po pierwsze tęskni za naszymi dziećmi, po wtóre nie 
może tam, gdzie jest, w Rewlu ${ }^{51}$, znaleźć dobrego miejsca, a po trzecie z jej projektowanego zamążpójścia teraz przynajmniej nic chyba nie będzie. Wobec trudności w dostaniu posady lub też awansowaniu na lepszą konduktorowie kolei Polacy żenić się nie mogą, jeżeli naturalnie nie chcą głodu cierpieć.

Dzięki również za obietnicę dopełnienia brakujących kart w tutejszym egzemplarzu pierwszej książki (nut) Kolberga.

Jakże teraz z Waszym zdrowiem? Mam nadzieję, że znacznie lepiej. Mnie także dokucza lewa noga. Bóle reumatyczne pojawiają się w niej zawsze z nastaniem wiosny i jesieni. W zimie zaś i w lecie jestem od nich wolny. W ogóle zaś czuję się zdrów, chociaż trochę zmęczony bezustanną a bezsensowną pracą.

Wykłady rozpocząłem 17 października. Wykładam: 1) ,antropofonikę i fonetykę ogólną” (dokładniej „antropofonikę i psychofonetykę") 3 godz[iny] tygodniowo, 2) „hymny RigVedy” 2 godz[iny] tygodn[iowo].

Sprawa dam w Komisji Antrop[ologicznej] stoi na dobrej drodze: Wydział Matem[atyczno]-Fizyczny, przyciśnięty przeze mnie w sposób wykluczający wszelkie ustępstwa z mej strony, postanowił oświadezyé się jednogłośnie oświadczyć się za zupełnym równouprawnieniem kobiet przy wyborze nie tylko na członków komisyj, ale także na członków samej Akademii. Wniosek w tym kierunku zostanie postawiony przez Wydział na listopadowym walnym posiedzeniu Akademii. Ciekawym, czy przejdzie.

N Za to w Uniwersytecie dopuszczono do słuchania wykładów tylko 3 farmaceutki; resztę kandydatek odpalono.

Tutejsi obrońcy istniejącego porządku urządzili sobie 14 paźdz[iernika] obławę na najspokojniejszych obywateli wychodzących z kościołów: bili kolbami kobiety, aresztowali sklepowych, zamykających sklepy o godz. 12 (jak zawsze w niedzielę) itd. W Wiedniu policja tratowała końmi publiczność, rąbała kobiety itd. W ten sposób uspokaja się tu umysły.

Bože! kýž jsem policajtem,

to je vyražení,

koho chce, toho si chytne

a dá do vězení.

Každý si ho musí vážit;

kdo naň zaškaredí,

pro urážku policajta

ve štokhauzu sedí.

Slyšte, lidé, pro výstrahu

mé smutné zpívání,

51 Dziś (od 1918 r.) Tallin. 
že se proti policajtům

sám bůh neubrání ${ }^{52}$.

We Lwowie na zgromadzeniu ludowym krzyczano o tych wypadkach: to sa nasze Kroże! $!^{53}$

Panna Schultz, pisząc do mnie niedawno, prosiła mnie, ażebym Wam przesłał mój egzemplarz jej [La] berceuse populaire, ponieważ Wasz miał zaginąć. Czy to prawda? Może zachodzi tu nieporozumienie, a cała sprawa jest anachronizmem i odnosi się do przesłania Waszego egzemplarza jeszcze tu, za granicę. Jeżeli zaś istotnie potrzebujecie owego egzemplarza, zechciejcie tylko napisać, a przeszlę go niezwłocznie.

Po powrocie ze wsi dzieci nasze nie mogą jakoś przyjść do siebie; mają ciągle do czynienia to $\mathrm{z}$ katarem, to $\mathrm{z}$ niestrawnością itd.

Od nas obojga najpiękniejsze ukłony i serdeczne pozdrowienia dla całego domu Państwa.

Wiernie oddany

J. Baudouin de Courtenay

16. L

Kochany Kolego!

Kraków, 23 XI [18]94

[Ul.] Radziwiłłowska 13

Dzięki Wam, jak też Pani za gościnność, okazaną Józefie Borowskiej. Przyjechała ona tu onegdaj, ku wielkiej uciesze naszych dzieci, i wręczyła mi Wasz list wraz z dodatkiem. Tego ostatniego nie omieszkam oddać według Waszych wskazówek. Piszę właśnie do Zawilińskiego ${ }^{54}$. Co ma zrobić z rękopismem o Cyganach po otrzymaniu opinii o nim? Czy go Wam odesłać, czy też zatrzymać tutaj? Kto to jest p[an] Wł[adysław] Kornel Vitellius Zieliński ${ }^{55}$ ? Pisywał on dawniej do mnie w sprawach heraldycznych. Musi to być człowiek już dosyć stary.

Dopiero teraz mogłem się zabrać do etymologii; za jakie dni 10 co najdalej dostanę żądanego kawałka. Przeklinam swoją ślamazarność, niedołęstwo i nieumiejęt-

52 Satyryczna kompozycja poetycka Karela Havlíčka Borovskiego (1821-1856) pt. Křest svatého Vladimíra.

53 Chodzi tu o tzw. rzeź kroską, która miała miejsce 22 XI 1893 r. w Krożach na Żmudzi. Po kasacji zakonu benedyktynek (1891 r.) władze carskie postanowiły przekazać Rosyjskiej Cerkwi Prawosławnej budynek kościoła Niepokalanego Poczęcia Najświętszej Maryi Panny. Miejscowa ludność była temu przeciwna, doszło do rozruchów, które stłumił oddział kozacki. W pacyfikacji zginęło 9 osób, ponad 50 osób zostało rannych, doszło też do aresztowania 71 osób. Wydarzenie w Krożach odbiło się szerokim echem we wszystkich zaborach. Roman Zawiliński (1855-1932), językoznawca, założyciel „Poradnika Językowego”. Władysław Kornel Vitellius Zieliński (1836-1895), historyk, regionalista Lubelszczyzny. 
ność koncentrowania się. Prócz tego, jako „Sarmata”, robię wiele „przez grzeczność”, tj. podejmuję się różnych drobnych robót, które mnie ani nie grzeją, ani nie ziębią, tylko czas marnie zabierają. Dobre by to było, gdybym umiał robić prędko, ale taki maruda jak ja powinien się trzymać jednego i basta. Przy tym nie wyłażę z korekt, siedząc w nich po uszy, a taka robota, rzecz prosta, ogłupia i odbiera ochotę do myślenia abstrakcyjnego.

Moje Streszczenie niemieckie mojej Próby teorii alternacji fonet [ycznych] okazało się za obszerne do „Bulletinu” 56 (dopiero teraz to spostrzeżono! Po złożeniu całej pracy! Jak gdyby nie można było tego od razu obliczyć!) i teraz ma wyjść osobno kosztem Smolki ${ }^{57}$ i moim. Smolka kazał to składać do „Bulletinu”, kazał Bystroniowi zmieniać mi pisownię na akademicką (bo i niemiecką pisownię posiada Akad[emia] tutejsza), a w dwa dni po tym oświadczył mi, że dla „Bulletinu” byłoby to za obszerne i za kosztowne. Bodaj to polskie oszczędności i polska delikatność. Przez „delikatność” nie powiedział mi tego teraz od razu, ale pozwolił robocie zajść tak daleko, ażeby narażać na koszta i daremną stratę czasu. Tak t Ten brak stanowczości i otwartości, właściwy tutejszym panom, jest dla mnie nieznośny. A w ogóle panuje tu taka obłuda i kłamstwo, że chyba trudno znaleźć coś podobnego w innych częściach świata. Do kłamstwa i obłudy wdrażają już dzieci od najmłodszych lat. Ich podręczniki szkolne są na to obliczone. Gał Główną dźwignią życia tutejszego jest благонамеренность ${ }^{58}$, ale to tak, że niech się przed nią schowa najgorliwsza moskiewska.

Dzięki za przysłanie kopii z Kolberga. Prawdopodobnie zabawka ta kosztowała Was z kilka rubli. Proszę bardzo, napiszcie, ileście zapłacili, a ja polecę zażądam od Komisji Antrop[ologicznej] zwrotu kosztów. Ponieważ to egzemplarz będący od własnością Komisji.

Czyście otrzymali egzemplarz kołysanek p[anny] Elli [von Schultz-Adajewsky] ${ }^{59}$ ? Posłałem go już dosyć dawno. Proszę go zatrzymać, bo mam oprócz niego inny.

Nie znam żadnego słownika słowackiego, więc sprawy tej załatwić nie mogę. Spróbuję jednak jeszcze rozpytywać.

Nie mam czasu opracowywać należycie swoich wykładów, ograniczam się więc krótkimi notatkami i programami, z których improwizuję podczas samych wykładów. Ponieważ wykładów nie piszę, a więc też ich też nigdy nie ogłoszę. Przejdą one jak dym, na podobieństwo większej części mojej niby-działalności naukowej. Zresztą niewielka to szkoda, bo na wypracowanie przyzwoite czasu nie mam; a więc mówię niekiedy rzeczy całkowicie cudze albo też też dosyć powierzchowne i nie-

56 Mowa o czasopiśmie „Bulletin International de L'Académie des Science de Cracovie”.

57 Stanisław Smolka (1854-1924), historyk, współtwórca krakowskiej szkoły historycznej, profesor i rektor Uniwersytetu Jagiellońskiego, sekretarz generalny AU w latach 1891-1902.

58 Ros. życzliwość.

59 J. Karłowicz przełożył tę pracę z języka francuskiego i opublikował w „Wiśle”: E. de Schoulz-Adajewska, Kołysanka ludowa, „Wisła” VIII, 1894, s. 824-837. 
dostatecznie zgłębione. Kto chce dziesięć srok trzymać za ogon, ten żadnej nie utrzyma. Słuchaczów mam bardzo niewielu, głównie, zdaje się, z powodu, że nie będą u mnie zdawać egzaminu. Na antropofonikę zapisało się coś około 11-12, a chodzi 5-7, na RigVedę zapisało się 4, a chodzi ostatecznie 2, a parę ostatnich razy tylko jeden, który jeszcze w dodatku nazywa się Nitsch, więc prawie nic. Drugi, zdaje się, zachorował. Nitsch zresztą jest pilny i interesuje się ${ }^{60}$. Ponie Nie ubliża mi jednak ta jednostkowość, boć przecie w r. 1868 na wykładach RigVedy Albrechta Webera ${ }^{61}$ ja byłem jedynym słuchaczem (choć zapisało się także czterech).

O czynach bohaterskich policji i armii tutejszej gazety warszawskie pisać chyba mogły; nie uczyniłem tego umyślnie, ażeby nie rozczarowywać dobrodusznych, wyobrażających sobie, że to jest skończone Eldorado.

Co do wszystek nie mogę w danej chwili wymyślić nic rozumnego. Również yr nazwy Gorgany objaśnić nie mogę. W moim słowniku rumuńskim znajduję „găura, tron, orifice, ouverture, cavité, issue", ale to chyba nie pozostaje w związku. Czy nie byłoby dobrze zapytać Hasdeu'a ${ }^{62}$ w Bukareszcie? (Bo[gdan] Petriceicu Hasdeu, Professeur á l'Universiti et Directeur général des Archives de l'État roumain á Bucarest (Roumanie)). Rozumie on także, mówi i pisuje po polsku.

Cenzura warszawska nie puszcza mi jednego wydawnictwa Komisji Antropol[ogicznej]. Ale jakoś Gebethner dawał sobie radę. Szanowna „spółka wydawnicza" traktuje sprawę apatycznie. Pisałem ongi o cenzurze do Majkowa Leonida ${ }^{63}$, obiecał złemu zaradzić, ale czy dotrzyma słowa, nie wiem.

Czy Adalberg ${ }^{64}$ wysłał Orzeszkowej (obecnie Nahorskiej ${ }^{65}$ ) Pieśni białoruskie ${ }^{66}$, a biskupowi Baranowskiemu ${ }^{67}$ inne rzeczy?

60 Kazimierz Nitsch w taki oto sposób ujął swoją uniwersytecką styczność z J. Baudouinem de Courtenay: „Na ogólny wykład Baudouina [Zarys antropofoniki i fonetyki ogólnej - M.R.] mało kto chodził, na pewno chyba tylko Janik, zapewne czasem Dobrzycki, może pierwszoroczny wtedy Stein, nie wytworzyło się więc żadne studenckie kółko. A na drugim Baudouina wykładzie: Objaśnienia hymnów Rig-Vedy, byłem od początku sam, bo nikt drugi nie miał choćby tak czysto formalnego przygotowania, jakie ja zdobyłem u Mańkowskiego. Musiałem tym być bardzo zainteresowany, skoro po formalnym przebyciu uniwersyteckiego czterolecia i pomimo żem bezpośrednio potem wszedł w jarzmo nauczycielskie, cały rok jeszcze chodziłem na wykłady Baudouina, nieraz jako jedyny słuchacz" (K. Nitsch, Ze wspomnień językoznawcy, Kraków 1960, s. 34-35).

61 Albrecht Weber (1825-1901), niemiecki indolog i historyk, profesor Uniwersytetu Berlińskiego.

62 Bogdan Petriceicu Hasdeu (1836-1907), rumuński filolog i historyk.

63 Leonid N. Majkow (Леонид Н. Майков) (1839-19oo), rosyjski filolog, historyk literatury rosyjskiej, wiceprezydent Petersburskiej Akademii Nauk.

64 Samuel Adalberg (1868-1939), historyk, paremiolog, folklorysta, autor Księgi przysłów i wyrażeń przysłowiowych polskich (Warszawa 1889-1894).

65 Eliza Orzeszkowa (1841-1910), pisarka okresu pozytywizmu, autorka m.in. Nad Niemnem. W 1894 r. została żoną Stanisława Nahorskiego (1826-1896).

66 J. Baudouin de Courtenay, Pieśni białorusko-polskie z powiatu sokólskiego, guberni grodzieńskiej, Kraków 1892.

67 Antoni Baranowski (Antanas Baranauskas) (1835-1902), biskup żmudzki i od 1897 r. sejneński, językoznawca, etnograf Litwy, poeta, matematyk. 
We wtorek jadę do Lwowa składać przysięgę nowemu panu. Kto to jest Adolf Strzelecki ${ }^{8}$ ? Nęka mnie o bibliografię folklorystyczną.

Dzięki za przyczynki do epigrafiki. Co to znaczy Psiakrew darmo zerco wściekło? Serdeczne pozdrowienia i cześć od nas obojga obojgu Państwu J. Baudouin

W jednym z wychodków włoskich znalazłem dość dowcipny zapis: Italia, ti ringrazio, perchè almeno da cacca non fa pagare il dazio ${ }^{69}$.

\section{L}

Kochany Kolego!

Kraków, 8 XII [18]94

Siedzę obecnie w etymologii. Muszę jednak znowu być niesłownym i opóźnić się o kilka dni stracone z konieczności na inne roboty i wyjazdy. 27 listopada wyjeżdżałem do Lwowa dla składania przysięgi (NB odbywało się to w sposób à la Chlestaków ${ }^{70}$ ), co zabrało mi przeszło trzy dni czasu. Parę dni temu znowu dostałem z Petersburga korektę sążnistego artykułu (za Словарь русских писателей и ученых), z którą się musiałem stante pede $e^{71}$ załatwić i natychmiast ją odesłać. Zajęło mi to dwa dni. Prócz tego miałem ciągle wykłady, co także pochłaniało pewną cząstkę czasu. Dodajmy do tego moje niedołęstwo i nieruchawość, a otrzymamy wyjaśnienie Pom opóźnienia. Pomimo to robię bez ustanku i mam nadzieję za kilka dni skończyć. Robota zaciąga się jeszcze wskutek tego, że nie ograniczam się żądanym kawałkiem, ale obrabiam od razu całe $B$. Prócz tego musiałem przejrzeć cały słownik Orgelbran$\mathrm{da}^{72}$, gdyż przecież nie tylko pod $B$ spotykają się wyrazy z pniami należącymi do $B$.

Obecnie pozbyłem się jednego z zajęć, które wprawdzie niewiele mi czasu pochłaniało, ale zawsze wymagało myślenia o sobie i mniej więcej obszernej korespondencji. Oto 29 listopada złożyłem z siebie godność przewodniczącego Komisji Antropologicznej, a wczoraj, 7, wybrano na to miejsce Malinowskiego. Ja z tymi panami nie mogę dojść do ładu. Postępowanie Wydziału Matem[atyczno]-Przyr[odniczego] było klasyczne. Dziś nie mam czasu wdawać się w szczegóły, ale - jeżeli Was to interesuje - mogę Wam o tym w przyszłości napisać obszerniej, dołączywszy kopię z mojej „abdykacji”. Urządzono mnie tu także bardzo ładnie ze streszczeniem niemieckiej rozprawy Próby teorii alternacji fonetycznych, przeznaczonym do „Bulletinu”

68 Adolf Strzelecki (1869-1911), pisarz, tłumacz, publicysta, działacz społeczny.

69 Wł. Italio, dziękuję ci, że przynajmniej od gówna nie muszę płacić podatków.

70 Aleksander Chlestakow, bohater Rewizora Mikołaja Gogola.

71 Łac. na jednej nodze, bezzwłocznie.

72 Inna nazwa Słownika języka polskiego Aleksandra Zdanowicza, Michała Bohusza Szyszki, Januarego Filipowicza, Waleriana Tomaszewicza, Floriana Ciepielińskiego i Wincentego Korotyńskiego (Wilno 1861). 
Akademii, a mianowicie dzięki osławionej „delikatności” Smolki. Jest to wyborna ilustracja stosunków krakowskich i tego wszystkiego, co się dzieje w sławetnym „hrabstwie umiejętności”. Jeżeli chcecie, opiszę Wam to kiedyś obszerniej, bo dziś oszczędzam czasu dla słownika.

Jeżeli Ludwik XIV mawiał l'état c'est moi $^{73}$, to pan hrabia Tarnowski z nierównie większym prawem może powiedzieć l'Académie c'est moi ${ }^{74}$. Stosunek do niego członków Akademii jest tak serwilistyczny, że może tylko wzbudzać pogardę. Kaprys pański góruje nad prawem, nad sprawiedliwością, nad wszystkim.

Wypytywałem się o tytuły słowników słowackich. Nikt mi nic nie umiał odpowiedzieć, $\mathrm{z}$ wyjątkiem Żegoty Paulego ${ }^{75}$. Oto tytuły dostarczone mi przez niego:

1) Bernolák Anton ${ }^{76}$ : Slowár Slowenskí Češko-Latinsko-Ňemecko-Uherskí seu Lexicon Slavicum Bohemico-Latino-Germanico-Ungaricum. Budae, typis et sumtibus Typographiae R[egiae Scientiarum] Universitatis Hungaricae, 1825-[182]8, 3 tomy (to zdaje się nie słowacki, ale czeski).

2) Jančovič Š̉efan ${ }^{77}$ : Novi mad’arsko-slovenski a slovensko-madiarski Slovnik, Sarvaš, literami Leopolda Réthyho $1848.12^{\mathrm{m}}-2$ tomy. $3 \mathrm{z}$ [ote] r[eńskie] 13 kr[ajcarów] mon[ety] k[o]r[o]n[o]w[ej].

3) Loos Josef ${ }^{78}$ : Wörterbuch der deutschen, ungarischen und slovakischen Sprache. Unter Mitwirkung Mehrerer von... Pest, Verlag von Wilhelm Lauffer, 1869. $12^{\mathrm{m}}$, 3 tomy - 7 zł[otych] r[eńskich] 60 kr[ajcarów] w[aluty] a[ustriackiej].

(Ten ostatni tytuł znałem przedtem; M: II. Deutschen - ungarischen - slovakischen Theil Pest 1870. A német, magyar et és tót nyelv szótára).

Czy chcecie, abym sprawdził którą z tych książek? Byłem już u Gebethnera i prosiłem, ażeby się dowiedzieli, czy można dostać Loosa. A może dałoby się to załatwić wprost z Warszawy, boć zdaje się, że tak Kraków, jak i Warszawa muszą się zwracać przede wszystkim do Lipska. A może dałoby się sprowadzić drogą antykwarską?

Czekam Waszych rozporządzeń (czy to nie rusycyzm?), a tymczasem posyłam serdeczne pozdrowienia.

Zawsze wierny

J. Baudouin de Courtenay

Pani ucałowanie rączek. Żona ukłony łączy. PS W Brockhausa Konversations Lexikon będzie mój artykuł: Polen (Volk, Ethnographie).

\footnotetext{
73 Fr. państwo to ja.

74 Fr. akademia [Umiejętności] to ja.

75 Żegota Pauli (1814-1895), historyk, archeolog, biograf, bibliotekarz, etnograf, krajoznawca.

76 Anton Bernolák (1762-1813), słowacki ksiądz katolicki, językoznawca, kodyfikator ortografii i gramatyki języka słowackiego.

77 Štefan Jančovič (1811-1893), słowacki leksykograf.

78 Josef Loos (1839-1878), węgierski językoznawca, nauczyciel w liceum w Bańskiej Bystrzycy.
} 
Kraków, 22 XII [18]94

[Ul.] Radziwiłłowska 13

Kochany Kolego!

Nareszcie grzesznik i kunktator wielki przysyła żądany przyczynek. Przeklinam tego, co wynalazł korekty, a następnie tego, co obdarzył Polaków ślamazarnością, niezaradnością i właściwą im, specyficzną delikatnością (to ostatnie stosuje się do Smolki, który przez „delikatność” ładnie mnie ubrał, narażając mnie na ogromną stratę, jako też mnie i siebie na straty pieniężne; dotyczy to drukowania owego niefortunnego streszczenia niemieckiego Alternacji).

Posyłam etymologie do wskazanego oddziału. Prawdopodobnie wypadnie je skrócić, gdyż w tych rozmiarach byłoby za dużo tego dobrego. Skracajcie więc, proszę, bez żadnych ceremonii, a będzie mi to wskazówką, jak mam dalej pracować. Materiału mojego proszę wcale nie żałować, gdyż - jeżeli mi Akademia udzielić raczy życia i zdrowia - mam zamiar (!!!) wydać osobny słownik etymologiczny jęz[yka] polskiego. W tym celu proszę Was o zachowanie mego rękopismu. Mam nadzieję dosłać kartkę próbnego arkusza, ażeby dopilnować dokładności swoich własnych przyczynków.

Marudziłem tak z przyczyn Wam wiadomych: 1) ogólna i stała (konstante Grös$s e^{79}$ ) moja sławetna natura i przyzwyczajenia mniej chwalebne; 2) przemijające, a jednak mocno dokuczliwe: korekty ze stron najrozmaitszych (?), nieznośna drukarnia Uniw[ersytetu] Jagiellońskiego, wstrętna bi biografia i bibliografia przysłana mi z Petersburga i inne t[ym] p[odobne] cukierki.

Zapewne wiecie już od Kryńskiego, że rękopism z Cyganami oddałem Kalinie ${ }^{80}$, który obiecał znieść się z Wami bezpośrednio.

Posyłam trochę kuponów na rachunek należnych Wam procentów.

Powiem Wam, kochany Kolego, że tu w Krakowie, „na ziemi ojczystej”, czuję się bardziej osamotnionym, aniżeli w furie Kazaniu, w Dorpacie, a nawet w Jurjewie ${ }^{81}$. Jedyny człowiek, z którym można było rozmawiać o kwestiach fachowych, a z którym zresztą rzadko się widywałem, Rozwadowski, wyjechał. Z Malinowskim niepodobna podtrzymywać żadnych stosunków opartych na otwartości i wolnych od podejrzeń i obłudy lub też szykan mniej lub więcej dowcipnych. Inni, niespecjaliści, jakoś także nie bardzo się nadają do obcowania, ale też mają, podobnie jak ja sam, nadzwyczaj mało czasu. W ogóle atmosfera tu ste jakaś stęchła i duszna; a co mnie

79 Niem. staty rozmiar.

80 A. Kalina (1846-1906), językoznawca, slawista, profesor i rektor Uniwersytetu we Lwowie, członek AU, współzałożyciel w r. 1895 Towarzystwa Ludoznawczego, założyciel i pierwszy redaktor "Ludu”.

81 Rosyjska nazwa Dorpatu. 
najwięcej razi, to absolutny brak szczerości, poddańczość, dobrowolne wyrzeczenie się sam wszelkiej samodzielności, obłuda itp. Rzecz prosta, iż iż są tu także ludzie inni, ale ogólny ton jest właśnie taki. Nigdy nie można być pewnym, czy zasymilowany przez tutejsze otoczenie osobnik mówi prawdę, czy też tylko mówi tak przez „delikatność", a tacy ingénus ${ }^{82}$, jak ja (czyli raczej tacy barbarzyńcy jak ja) łapią się na to i źle na tym wychodzą. Otrzymać odpowiedź łu prostą na moje zapytanie należy tu do rzeczy najtrudniejszych. Nie darmo roi się to miasteczko czarną żandarmerią. No, ale dosyć o tym.

Od Tołoczanowa ${ }^{83}$ otrzymacie na mój rachunek 3 rub[le] 25 kop[iejek].

A co mam robić ze słownikiem słowackim? Czy sprawdzić którykolwiek z wymienionych w moim ostatnim liście?

Nominalna eena wartość kuponów jest $15 \mathrm{r}$ [ubli]; po odtrąceniu 5\% wypada $14 \mathrm{r}$ [ubli] $75 \mathrm{k}$ [opiejek]. Zap Tyle zapisuję też na Wasz rachunek.

Pani ucałowanie rączek, a całej Rodzinie Państwa najszczersze życzenia i najserdeczniejsze pozdrowienia od nas obojga

Wiernie oddany

J. Baudouin

\section{Cracow Letters of Jan Baudouin de Courtenay to Jan Karłowicz from 1894 Summary}

The presented correspondence includes nine letters and nine postcards from 1894, sent by Jan Baudouin de Courtenay to Jan Karłowicz. Among other things, it shows the scientific and extra-scientific relations in Cracow in the last decade of the $19^{\text {th }}$ century - although, owing to the person of the addressee, it also refers to Warsaw. The main scientific topics are 1) comments on the etymology of lexemes studied by J. Karłowicz for a dictionary of foreign words which were used in Polish and had a less clear origin; 2) matters related to changes in Polish orthography; and 3) comments on the edition of the so-called Warsaw dictionary.

82 Fr. ingénu 'prosty, otwarty, szczery'.

83 Arkady A. Tołoczanow (1830-1897), rosyjski urzędnik w Królestwie Polskim, bibliofil, korespondował z J. Baudouinem de Courtenay (listy Tołoczanowa do Baudouina są przechowywane w filii Archiwum Rosyjskiej Akademii Nauk w Petersburgu), w testamencie przekazał swój pokaźny księgozbiór Uniwersytetowi Warszawskiemu. 